\title{
Review of Vjatsheslav Zilanov, Mister Russland Arktis? (Россия теряет Арктику?)
}

Vjatsheslav Zilanov. Mister Russland Arktis? Translated from Russian to Norwegian by Svetlana Petrovna Jakobsen and Reidar Jakobsen. Oslo: Vidarforlaget AS. 2018. 281 pages. ISBN: 9788279902867. (Originally published as Россия теряет Арктику? in 2013.)

Reviewed by Gunnar Nerdrum, retired Norwegian Supreme Court attorney, former member of the Paris Bar and the Moscow Bar.

This book merits interest, particularly by Norwegians, since it principally deals with Russian-Norwegian relations in the Arctic oceans.

Born in 1938, Vjatsheslav Zilanov participated on and often led the teams from the Soviet Union and later (from 1991) the Russian Federation negotiating fisheries issues with Norway. He started his career in 1957 on a research vessel and since then has published nine books and more than 300 scientific articles on various subjects related to high-seas fishing. He has held posts as vice-minister for fisheries and is currently a member of different groups of experts dealing with questions related to fisheries and the exploitation of valuable organisms in the oceans. He is considered a leading specialist on issues related to the sustainable exploitation of the wealth of the seas.

In this book Zilanov gives snapshots from the negotiations in which he took part from 1973 and onwards. Of particular interest for Norwegians are his recollections and appreciation of the main Norwegian negotiators at that time, Jens Evensen and Arne Treholt.

The negotiations in the 1970 s finally led to the "grey zone" agreement (gråsoneavtalen) of 1978. While heavily criticised in Norway it was expressly renewed annually and had the merit of establishing an agreed delimitation in parts of the disputed area at sea.

Zilanov deviates from this account to comment on the delimitation agreement in the Bering Sea between the Soviet Union and the United States in 1990 . He characterizes that agreement as a "traitors' agreement" between the two countries'

(C) 2019 Gunnar Nerdrum. This is an Open Access article distributed under the terms of the Creative Commons Attribution-NonCommercial 4.0 International License (https://creativecommons.org/licenses/by-nc/4.0/), allowing third parties to share their work (copy, distribute, transmit) and to adapt it, under the condition that the authors are given credit, that the work is not used for commercial purposes, and that in the event of reuse or distribution, the terms of this license are made clear.

Citation: Gunnar Nerdrum. “Review of Vjatsheslav Zilanov, Mister Russland Arktis? (Россия теряет Apктику?)” Arctic Review on Law and Politics, Vol. 10, 2019, pp. 135-137. http://dx.doi.org/10.23865/arctic.v10.1675 


\section{Gunnar Nerdrum}

respective secretaries of state at that time, Eduard Shevardnadze and James Baker. The agreement was immediately ratified by the competent U.S. bodies but has yet to be ratified on the Russian side, although it has been provisionally applied by both parties since then.

Zilanov was not on the negotiating team that concluded the Barents Sea Treaty between Russia and Norway in 2010. That treaty established a delimitation line that is placed almost in the middle between the pretentions of the two countries. Zilanov however saw no reason to "give" the Norwegians some $80,000 \mathrm{~km} 2$ of the seabed and water column. The first edition of this book had the significant title The Failure of the President in the Barents Sea (Баренщеморская ошибка Президента). He believes the agreement detracts from the Russian positions with respect to:

1. Loss of fish-catching territories in the Western Barents Sea

2. Weakening Russia's arguments as against for the Norwegian Fish Protection Zone around Svalbard (Spitsbergen)

As for the first objection, there is a system of reciprocal supervision of the fish catches. The Joint Norwegian-Russian Fisheries Commission meets once a year and has done so since 1975. It makes decisions on the total fish catches, divided into different species, with allocation to the two countries, as well as quotas for fishing boats from other countries. On the whole, this system has been working well despite fluctuations in the diplomatic climate between the two countries.

As for the second objection, it is correct that Norway in 1977 established a "non-discriminating fishing protection zone" of 200 miles around Svalbard. Russia has not recognized this zone, nor have most other countries. But it works. One reason for this is, perhaps, that Norway has always granted quite generous quotas to fishing boats from other nations. In return, these boats are obliged to follow Norwegian rules and accept Norwegian jurisdiction.

Many foreign actors have contested the regime before Norwegian courts, and several cases have also been heard before the Norwegian Supreme Court. However, the judges have always found it possible to avoid taking a position on the crucial question, namely: does Norway have a unilateral right to pronounce such a zone in waters that have been considered "international" by others until now?

Zilanov is particularly upset by the fact that the Norwegian Coast Guard patrols the fish protection zone and arrests Russian (and other) vessels and escorts them to a harbour in the mainland of Norway. Thus, the vessels are prevented from fishing while under arrest. He reports rather shocking scenes, in particular when the Russian trawler Elektron some years ago fled from the Norwegian inspection vessel, with some of the Norwegian controllers on board, and returned to undisputed Russian waters.

A "Norwegian threat"? It is strange to see in Zilanov's account that little Norway may be considered a threat to a super-power such as the Russian Federation, as we in Norway have always focussed on with the "Russian threat". The "Russian bear" is presumed to be greedy for the land and the ice-free harbours of Finnmark. However, 
as professor Jens Petter Nielsen has demonstrated, there has never been any reality to these suppositions ${ }^{1}$.

On the other hand, we have seen historically in Russia warnings of a perceived "threat" from Norway. This has primarily been based upon the partly doubtful experiences after the Norwegian colonisation from the 1860s on the Murmansk Coast. In fact, the czarist administration encouraged this immigration. They looked at the prosperity in the adjacent Finnmark communities and thought that hard-working Norwegians would serve as a good example to the Russians. Russian authorities granted the colonists substantial privileges, including the right to sell liquor, which turned out to have deplorable consequences for the Sami, Finish and Russian population. Thus the argument arose: Why should these newcomers have rights that we Russians deny our own kinsmen?

Norwegian hunters in the Arctic also had real advantages. As their Russian competitors were blocked by the ice in the White Sea up to the end of May, the Norwegians benefited from the Gulf Stream, either up to Svalbard or eastwards to Novaya Zemlya. So, when finally, the Russian hunters came to the sealing fields, the Norwegians had already been hunting there for quite a time.

There was even a fear within leading circles in Russia that this might provide a basis for claims on annexations of land. To protect the country against this calamity, some Nenets families were transported to settle on Novaya Zemlya. This island was a thriving community by the 1920 s when Vsevolod Vasnetsov visited it many times as part of research teams on the legendary "Persei". ${ }^{2}$

In recent years a threat has also been felt in the military field. Norway is a member of NATO, which considers the R.F. its main "enemy". In the past, the Norwegian Government made many decisions to reassure Russia. For instance, it did not allow joint allied exercises in Finnmark, the county adjacent to the Kola Peninsula. Now these restrictions have been lifted. Americans train with other NATO forces close to the border, and American soldiers reside permanently in Norwegian military camps. This too will evidently be felt as a "threat" on the Russian side.

Even if I am not convinced by the author's arguments and conclusions, it is nevertheless interesting to review these experiences from the perspective of a prominent partner - and leader - of Soviet/Russian negotiating teams, and therefore the book is strongly recommended. In addition, it includes many illustrations and statistics of interest.

\section{NOTES}

1. Nielsen, Jens Petter: Russisk fare for Norge? Ottar no. 192, Tromsø 1992, pp. 33-40.

2. Васнецов, В. А.: Под звёзднымм флагом «Персея», Ленинград 1976. In particular his meeting with the gifted nenets artist Tyko Vylka. 